\title{
INTRODUCTION
}

\section{The Body Between the Protestant Souls and Nascent Na- tion-States: Physical Education as an Emerging School Subject in the Nineteenth Century}

\author{
Daniel Tröhler \\ Johannes Westberg
}

Today, physical education is an established part of the curriculum of compulsory schooling. Taken for granted as a school subject, yet considered a minor school activity whose mastery and excellence are not decisive for the school careers and thus the life chances of the younger generation, physical education has not enjoyed research attention as have, for instance, language teaching, history or geography, let alone religious instruction. Physical education is publicly undisputed as a curriculum requirement, but it is not really highly valued. The comparatively low public esteem and physical education's lack of necessity for textbooks - a prominent field of research - make physical education a bit of a Plain Jane in educational discourse.

The comparatively low regard in which physical education is held in research ${ }^{1}$ has its equivalence in the daily practice of school activity. Physical education instructors might react to this neglect by citing - in Latin-the famous phrase Mens sana in corpore sano, "a healthy mind in a healthy body," indicating that intellectual health (also) depends on physical health. That reaction could, however, trigger reactions from a sophisticated aficionado of the humanities, who knows that Mens sana in corpore sano is an abbreviated version of a sentence from Juvenal's Satire $X$ in which he was discussing not sports but the value of wishing and praying. In this context Juvenal says, "[...] if you must pray for something [...] then ask for a healthy mind in a healthy body, demand a valiant heart for which death holds no terrors." ${ }^{2}$ Juvenal was obviously making fun of the body culture of the Ancient Romans, and he saw a need to pray that those who trained their bodies so extensively would care equally for developing a sound mind and a good heart, too.

1 The sports sciences are an exception, for they indeed have historical interest. Interestingly enough, this particular historical research is somewhat isolated from mainstream history of education. Another exception is research conducted in the field of gender studies.

2 Juvenal, The Sixteen Satires, 3rd ed., trans. Peter Green (London: Penguin Books, 2004), 86.

Daniel Tröhler is Professor in Foundations of Education at the Department of Education, University of Vienna, Austria.

Email: daniel.troehler@univie.ac.at

Johannes Westberg is Professor in Education at the School of Humanities, Education and Social Sciences, Örebro University, Sweden.

Email: johannes.westberg@oru.se

Nordic Journal of Educational History 2017. (c) Daniel Tröhler and Johannes Westberg. This is an Open Access article distributed under the terms of the Creative Commons CC-BY4.0 License (http://creativecommons.org/licenses/by/4.0/). 
Against this background, physical education is constantly being a bit discredited-even more so, because at times it was closely connected to un-reflected masculinity, military programmes and war preparation; and in some places physical education policy was and is indeed not domiciled in the ministries of education but in the ministries of defence. Given its commitment to enthusiastically participating in the "educationalization of the world,"3 the several branches of education research are of course much more devoted to finding educational solutions to political challenges and social tensions rather than to helping to train the alleged future killing machines or cannon fodders. To serve anything connected to power and/or war aspirations cannot be located in the moral(istic) realm of education research.

One of the tremendous advantages of the history of education is that - potentially-it does not need to be so devoted to the moralistic agenda of education in general, in policy or in research. Quite the contrary, education history precisely fulfils its function when it does not participate in trends of an educationalised world but when it analyses its causes, its intellectual and institutional developments and trajectories and its discursive effects in the way that education research is being defined as appropriate and helpful: providing 'evidence' for policy, for instance. The fact that this is only rarely done does not mean that its potential does not exist but that the advocates of the critical function of the history of education are obviously in need of offering 'evidence' for their position.

Part of this agenda is to excavate research topics neglected by dominant discourses or epistemologies. Physical education is an outstanding field of research not only because it is not the target of international assessment programmes. Those programmes might indeed find that Norwegians are doing better in cross-country skiing than the Portuguese and that the Finnish are better in ski jumping than students in Hong Kong or Singapore, but they would not know how these athletic competencies would be an answer to what kind of real life challenges that these assessment programmes assume to exist. Physical education tells us a lot about the making of a school subject in modernity, for it was not included in the curricula of early modern general education. There was indeed horseback riding, fencing or dancing in the curricula of the knight academies and educational institutions for the sons of noblemen who did not wish to enter religious careers - but those particular exercises were not transferred into the educational institutions of elementary schooling for the masses.

The crucial question then is related to the 'making of': telling not only the history or the career of an obviously modern school subject in compulsory schooling but also revealing the very mechanisms of modern schooling, its logics of policy and its national and religious entanglements. The diffusion of physical education was a transregional movement in a time when the slowly emerging nation-states were not yet seen as inevitable forms of political organization. Yet-and this is the fundamental thesis of this special issue-physical education would probably not have entered the curriculum of compulsory schooling if the nation-states themselves had not emerged as educational projects, relying heavily on the educational making of future loyal citizens of the nation-state and its respective vision of social order that

3 Daniel Tröhler, "Educationalization of Social Problems and the Educationalization of the Modern World," in Encyclopedia of Educational Philosophy and Theory, ed. Michael A. Peters (Singapore: Springer, 2016). 
was sought to be implemented by institutions based on a constitution. ${ }^{4}$ The Nordic States were no exceptions in that respect. Their different routes towards becoming nation-states nevertheless makes them particularly interesting cases. ${ }^{5}$

\section{Physical education in the Nordic countries}

One of the European centres in this emerging movement of physical education was late eighteenth century Copenhagen. In its rather unique amalgam of deeply Lutheran commitment, monarchic structure and simultaneous interest in the (also French) Enlightenment, it became a melting pot for different educational movements and all too often a place for exiles, foremost for German liberal Lutheran theologians and educational reformers. Johann Bernhard Basedow, the initiator of the German Philanthropists after 1768, was appointed professor of moral philosophy, belles-lettres and theology at the knight academy, Sorø Academy, in Denmark as early as in 1753. However, due to his rational theology, he was forced to move from there to the Gymnasium Christianeum in Altona near Hamburg, which, at the time, still belonged to Denmark.

Years later, it worked the other way around. The philanthropist Peter Villaume, a Huguenot descendant and theologian, decided in 1793 to move to Fuirendal on the Danish island of Funen because of his radical rationalism. ${ }^{6}$ Villaume had published, in 1787, writings on physical education in the context of an encompassing education for the "happiness of mankind" (Glückseligkeit des Menschen). ${ }^{7}$ The breeding ground for educational reforms in Denmark was obvious, as can be seen in the Committee for the improvement of Danish schools (Commissionen for de Danske Skolers bedre Indretning), ${ }^{8}$ which was founded in 1789 by Frederick VI, then regent (and later king) of Denmark and Norway.

4 Daniel Tröhler, "Curriculum History or the Educational Construction of Europe in the Long Nineteenth Century," European Educational Research Journal 15, no. 3 (2016), 279-97.

5 Daniel Tröhler, "Curriculum History in Europe: A Historiographic Added Value," Nordic Journal of Educational History 3, no. 1 (2016), 3-24.

6 "Ved sin radikale rationalisme kom V. imidlertid i den grad paa kant med det reaktionaere Wöllnerske styre at han 1793 bestemte sig til at opgive sin stilling og drage til Danmark," Dansk Biografisk Leksikon vol. 15, 545. http://denstoredanske.dk/Dansk_Biografisk_Leksikon/Uddannelse_og_undervisning/P\%C3\%A6dagog/Peter_Villaume.

7 Peter Villaume, Von der Bildung des Körpers in Rücksicht auf die Vollkommenheit und Glückseligkeit des Menschen, oder über die physische Erziehung insonderheit. In Allgemeine Revision des gesammten Schul- und Erziehungswesens von einer Gesellschaft praktischer Erzieher, Vol. VIII (Vienna: Rudolf Gräffer und Compani, Schulbuchhandlung, 1787), 211-92. At that time, Villaume had been teaching philosophy at the famous Joachimsthalsche Gymnasium in Berlin, a modern knight academy that two decades later would become the ultimate centre of the gymnastics movement in Germany; see the article by Daniel Tröhler in this issue.

8 Members were: count Heinrich Ernst Schimmelmann, the ethnic German privy councillor and minister of finance, who worked towards the abolition of serfdom in Schleswig and with the improvement of elementary education for the masses following Rochow's ideas (whereas his wife, Magdalene Charlotte Hedevig Schimmelmann-Schubart, favoured Pestalozzi's ideas); Johann Ludwig Graf von Reventlow, count and delegate of the "chamber of pensions," who lived in Funen (to where Villaume would move in 1793, see above); Frederik Carl Trant, founder of several schools and in 1794 of a teacher seminar; Christian Brandt civil servant, privy councillor and school director; Nikolai Edinger Balle, the Lutheran Bishop in Sjælland; and Blaagard Magnus Hoffmann Sevel, the inspector for teacher education. The commission was to send two teachers to Pestalozzi in 1802, Johann Christian Ludvig Strøm and Johann Henrik Anton Torlitz, to learn the fundaments of a better educational method as basis for educational reform in Denmark. See Rebekka Horlacher and Daniel Tröhler, eds., "King Christian VII. to Pestalozzi, 20 November 1802," in Sämtliche Briefe an Johann Heinrich Pestalozzi, Band 1 (Zurich: NZZ Libro, 2009). 
It seems that 1793 - the year that Villaume moved to Denmark-was a decisive year, at least with regard to physical education. In this very year, the Lutheran theologian Johann Rudolf Christiani was nominated to become court chaplain in Copenhagen. Based on the writings of the German Philanthropists, Christiani opened the Copenhagen Philanthropin in 1795. The Philanthropin was a school designed to give sufficient attention to children's bodies through hygiene and exercise. To fulfil this quest, Christiani hired Franz Nachtegall, another Lutheran theologian of German origin who was born in Copenhagen. Nachtegall was devoted to the concept of physical education proposed by another German Philanthropist and theologian, Johann Christoph Friedrich GutsMuths, who had been a teacher at the Philanthropin in Schnepfenthal headed by the Lutheran minister Christian Gotthilf Salzmann since $1784 / 85 .{ }^{9}$ GutsMuths began to teach physical exercises in $1786,{ }^{10}$ and in 1793 he published his widely read and often translated treatise Gymnastik für die Jugend. Enthalten eine praktische Anweisung zu Leibesübungen, ${ }^{11}$ published in Danish in an abbreviated version in $1799 .^{12}$

Nachtegall was not only fond of the German ideas of physical exercise but also had been taught "fencing and vaulting by the old French fencing master Embs, and soon acquired skills in both arts, but especially the latter." ${ }^{13}$ It was due to Copenhagen's particular political and cultural context that an amalgam of French ideas of physical education, oriented towards an aestheticised ideal of a nobleman, and German ideas of physical education oriented more towards utilitarian ideas of the rising bourgeoisie became possible. From this amalgam, different trajectories across

9 Schnepfenthal, founded in 1784 by Salzmann, was an 'international' place, which can be seen in the fact that Pestalozzi's disciple Gottlieb Anton Gruner, acting as private tutor of Erich Lehnsgraf von Bernstorff (1791-1837) from Copenhagen, spent some four months between June and September of 1803 at this Philanthropin. Gruner had become acquainted with Erich Lehrsgraf von Bernstorff during a stay in Copenhagen in 1801. See Horlacher and Tröhler, (2009) 684-87.

10 It can be assumed that GutsMuths was familiar with Villaume's manuscript on physical education (Villaume (1787), see Johann Christoph Friedrich GutsMuths, Gymnastics for Youth: Or a Practical Guide to Healthful and Amusing Exercises for the Use of Schools ... Freely translated from the German of C.G. Salzmann (London: F. Johnson, St. Paul's Church-Yard, 1800, 70). GutsMuths certainly knew from his visits to the original Philanthropin in Dessau that the children (who came from noble families) were taught, among other subjects, fencing, dancing and horseback riding on the one hand and "physical exercises" such as threshing, plane, woodwork and woodturning on the other. Johann August Heinrich Ulrich, "Geschichte des Philanthropins zu Dessau," in Pragmatische Geschichte der vornehmsten katholischen und protestantischen Gymnasien und Schulen in Deutschland aus authentischen Originalnachrichten, Erster Band (Leipzig: Weygandsche Buchhandlung, 1780), 265-72. Obviously, physical education included both - the traditional training of nobility and basic vocational training - but it was not yet physical training as we would know it today in our schools.

11 Johann Christoph Friedrich GutsMuths, Gymnastik für die Jugend: Enthalten eine praktische Anweisung zu Leibesübungen (Schnepfenthal: Verlage der Buchhandlung der Erziehungsanstalt, 1793).

12 Johann Christoph Friedrich GutsMuths, Kort Anviisning til Legemsøvelser: Et Udtog af Gutsmuths Gymnastik, trans. V. K. Hjort (Copenhagen: S. Poulsen, 1799). An English translation appeared a year later: Gymnastics for Youth; or a practical guide to healthful and amusing exercises for the use of schools, see GutsMuths (1800). For more information on GutsMuths and his concepts of physical education, see the article by Rebekka Horlacher in this issue.

13 Fred Eugene Leonard, Physical Education in Denmark (n. p.), 1n. It was not possible to identify this "French fencing master Embs." Other sources talk of a fencing master "Ebbs" teaching young Nachtegall (https://de.wikipedia.org/wiki/Franz_Nachtegall). According to a personal communication (in October 2016) by Mette Buchardt, Aalborg University, French fencing masters in Copenhagen are recorded, but no names are handed down and none similar to Ebbs or Embs. 
different emerging education systems arouse, and they met repeatedly and found supporters and advocates in very different contexts across the nineteenth century. Especially noteworthy is the Swede Pe(h)r Henrik Ling, son of Lars Peter Ling, a Lutheran minister in Södra Ljunga, and a Lutheran theologian himself.

After his studies at the University of Uppsala, Ling went on a European journey, starting in 1799 in Copenhagen, where he became acquainted with Nachtegall and his concepts of physical education, and he also joined fencing classes taught by two French immigrants. ${ }^{14}$ In 1804 , Ling went back to Copenhagen, ${ }^{15}$ where he took intensified fencing lessons, again taught by the two French fencing masters, and restored his fragile health. Fencing:

cured a paralysis in one of his arms. He became an excellent fencer and over the years earned his living by giving fencing instruction. Unlike fencing, which was seen as a 'chivalrous' sport, gymnastics was seen as 'common' in 'respectable circles'. Nevertheless, Ling attended gymnastics with the leading Danish gymnastics instructor F. Nachtegall, whose gymnastics were inspired by GutsMuths. ${ }^{16}$

With restored health and convinced of the healing power of systematised fencing, Ling became master of fencing at the University of Lund in 1805 and started to propagate his ideas on physical education throughout Sweden. In parallel, Ling became acquainted with the Swedish past and became involved in Nordic mythology. As a co-founder of the Gothic association (Götiska Förbundet), in 1811, he was devoted to developing a particular Swedish nationalism out of a praised past, against the background of the Swedish new constitution of 1809 and the loss of Finland that same year. ${ }^{17}$ In 1813, Ling became fencing master at the Swedish Royal War Academy at Karlberg and received a royal permit to establish a gymnastic school, the Royal Central Gymnastic Institute (Gymnastiska Centralinstitutet). ${ }^{18}$ Soon his physical exercises, located between health and fighting, were introduced in many schools and in the army; gymnastics and national romanticism went hand in hand, ${ }^{19}$ just as they had in Germany.

Ling, who was appointed gymnastics and swordsmanship teacher at the higher artillery grammar school in Marieberg (Högre artilleriläroverket i Marieberg) in 1818, became famous not only in Sweden but also in other parts of the Western world, including the United States, England and France. Ling's Swedish gymnastics were also

14 Gunnar Carlquist, ed., Svensk uppslagsbok. vol 17 (Malmö: Svensk Uppslagsbok AB, 1937), 304-07.

15 It is not clear when Ling returned to Copenhagen or if he even was gone from Copenhagen at all; see also Ove Korsgaard, "Gymnastik i kosmisk perspektiv," in Den gamle nyreligiøsitet: Vestens glemte kulturarv, ed. Mette Buchardt and Pia Rose Böwadt (Copenhagen: Forlaget Anis, 2003), 258.

16 Korsgaard (2003), 251-66. We wish to thank Mette Buchardt from Aalborg University for pointing us to this article (and for the translation).

17 Jens Ljunggren, Kroppens bildning: Linggymnastikens manlighetsprojekt 1790-1914 (Stockholm: Symposion, 1999); Anne Berg, Kampen om befolkningen: Den svenska nationsformeringens utveckling och sociopolitiska förutsättningar ca 1780-1860 (Uppsala: Uppsala universitet, 2011), ch. 3.

18 Esbjörn Larsson, Från adlig uppfostran till borgerlig utbildning: Kungl. krigsakademien mellan åren 1792 och 1866 (Uppsala: Uppsala universitet, 2005), 224-26.

19 Ove Korsgaard, “Gymnastik og romantik: med Pehr Henrik Ling som optic," in Romantikkens verden: Natur, menneske, samfund, kunst og kultur, ed. Ole Høiris and Thomas Ledet (Aarhus: Aarhus Universitetsforlag, 2008), 231-47. 
popular in Germany, where his concept of physical education was often favoured over Turnvater Jahn's conceptions, which were often less popular due to Jahn's determined form of nationalism. ${ }^{20}$ An important translator here was Hugo Rothstein, who was a Prussian officer, writer, educator and gymnast but a fundamental critic of the German Turners and their system of gymnastics. Rothstein became acquainted with Swedish gymnastics when he travelled to Sweden, and he introduced it in Prussian military and civil physical training programmes. ${ }^{21}$ In the military it was labelled Wehrgymnastik (defence gymnastics), and in civil training programmes it was called Heilgymnastik (therapeutic gymnastics). ${ }^{22}$ Both attempts found their admirers, such as Albert Constantin Neumann, ${ }^{23}$ a physician, and Wilhelm Angerstein, ${ }^{24}$ a gymnast and publicist. Rothstein was in that sense a pioneer, as it was this instrumental militarist-nationalist idea of gymnastics that eventually acted as a vehicle for the full implementation of gymnastics as a school subject in the German curricula on all levels towards the end of the nineteenth century.

\section{The Protestant soul and the emerging nation states}

Of course, it is a paradox that ultimately, this physical education programme-which developed first in Copenhagen, by melding German Philanthropic ideas with French fencing techniques, and then developing in the frame of Swedish or Nordic nationalism-became popular in Germany in order to combat Jahn's conception of physical education that was built on German nationalism. This example shows, however, how educational ideas travel and are received if they fit into the overall curricular aspirations of forming the future citizens of a given (or emerging) nation. The active agents of this particular reform, physical education, were obviously deeply rooted in Protestant, mostly Lutheran, perceptions of life and were concerned less with physical education in regard to the industriousness of a self-sufficient holistic citizen, as had been the case with the Swiss Reformed Protestant Pestalozzi. ${ }^{25}$ In the Lutheran traditions, the envisaged harmonious formation of the soul, called Bildung, was to have an outer equivalent, the harmonious nation-state, which later would become epitomised in

20 Note that Germany played an important part in the dissemination of Ling's gymnastics to, e.g. Belgium; see Pascal Delheye, "Struggling for Gymnastics in Belgium: The Rhetorics of the Battle of the Systems (1860-1914)," Stadion: Internationale Zeitschrift für Geschichte des Sports 32, no. 1 (2006), 60.

21 Hugo Rothstein, Die Gymnastik, nach dem Systeme des Schwedischen Gymnasiarchen P. H. Ling. Zweiter Abschnitt: Die Pädagogische Gymnastik (Berlin: Schröder, 1847). See also Wolfgang Eichel et al., Geschichte der Körperkultur in Deutschland 1789-1917, Band 2 (Berlin: Sportverlag, 1973).

22 Hugo Rothstein, Die Gymnastik, nach dem Systeme des Schwedischen Gymnasiarchen P. H. Ling. Vierter Abschnitt: Die Wehrgymnastik (Berlin: Schröder, 1851); Hugo Rothstein, Die Gymnastik, nach dem Systeme des Schwedischen Gymnasiarchen P. H. Ling. Dritter Abschnitt: Die Heilgymnastik (Berlin: Schröder, 1847).

23 Albert Constantin Neumann, Die Heil-Gymnastik: oder die Kunst der Leibesübungen, angewandt zur Heilung von Krankheiten nach dem Systeme des Schweden Ling und seiner Schüler Branting, Georgii und de Ron, sowie nach eigenen Ansichten und Erfahrungen; ein Bericht nach einer auf Kosten des Preussischen Staats unternommenen Reise nach Stockholm, London und St. Petersburg (Berlin: Jeanrenaud, 1852).

24 Wilhelm Angerstein, Zur Wehrgymnastik und militärischen Jugenderziehung: Nach zwei Vorträgen, gehalten im Berliner Turnlehrer-Verein (Berlin: W. E. Angerstein, 1880).

25 Johann Heinrich Pestalozzi, "Über Körperbildung als Einleitung einer Elementargymnastik, in einer Reihenfolge körperlicher Übungen," in J. H. Pestalozzi, Sämtliche Werke, Kritische Ausgabe, Band 20 (Zürich: Orell Füssli, 1956), 45-68. 
the notion of the Volk, be it in Denmark by Nikolai Grundtvig or in Germany by the academic school of thought called Geisteswissenschaftliche Pädagogik. ${ }^{26}$

Accordingly, developments in a Catholic country becoming more secular (laicist), such as France, were quite different. France had no broad public culture of gymnastics, and the schools were very reluctant to introduce it into the curricula. Towards the end of the Second Empire, which ended with the Franco-Prussian War in $1870 / 71$, gymnastics had entered the school curricula only of the institutions of higher education (lycées), the higher levels of elementary schooling and teacher education. ${ }^{27}$ However, and in contrast for instance to Prussia and the German Reich, France had no system of gymnastics teacher education; gymnastics teachers were former soldiers with very low social status within the educational institutions; only in 1907 was a physical training college founded at the initiative of the lycées and colleges, and only in 1933 was a separate, state-run gymnastics teacher training institution opened. ${ }^{28}$

The major difference between France and other European nation-states-foremost Germany - was that France never thought it necessary to 'invent' the French nation: It was a given fact. The interrelation between gymnastics and nation-building was no issue. The French authorities were quite alarmed by the development in Germany, but they preferred to look to England and its focus on sports and foremost at theologian Thomas Arnold, who had become famous, for instance, with his publication, Sermons Preached in the Chapel of Rugby School. ${ }^{29}$ And with regard to education, the Swedish system of physical training was crucial to the French, as the publication by Georges Demenÿ, L'Éducation physique en Suède [Physical Education in Sweden] shows. ${ }^{30}$ The Belgians, in their cultural proximity to the French, followed only some 10 years later with a publication under the same title, written by an army captain and head of a military school, Lefebure, ${ }^{31}$ who began the book by quoting "Mens sana in corpore sana [...]." 32

These examples show how military ambitions (as fundamental activities in defending the nation-states) and schooling (as fundamental means to stabilising the nation states) are not as divided as one may assume. The idea and existence of the nation-state always depended not only on loyal civil citizens, fabricated by the school, but also on brave and competent soldiers. It is the realm of the latter that has for a very long time been largely ignored by the educational sciences in their dedication to the good and pure inward life. Yet, very recent initiatives provide evidence of this: for instance, the "Education, War, \& Peace" theme of the ISCHE conference in 2014,

26 Alexander Maier, "Bildung zur Nation. Geschichtserzählung und kulturelle Identität als sakral-pädagogisches Programm bei Nikolai Grundtvig," Bildungsgeschichte: International Journal for the Historiography of Education 5, no. 2 (2015), 162-81; Daniel Tröhler, "The German Geisteswissenschaftliche Pädagogik and the ideology of Bildung," in Languages of Education: Protestant Legacies, National Identities, and Global Aspirations, ed. Daniel Tröhler (New York: Routledge, 2011), 148-63.

27 Françoise Mayeur, Histoire de l'enseigenment et de léducation III: 1789-1930 (Paris: Perrin, 1981).

28 Mayeur (1981), 661-64.

29 Thomas Arnold, Sermons Preached in the Chapel of Rugby School (London: B. Fellowes, 1833).

30 Georges Demenÿ, L'Éducation physique en Suède (Paris: Société d’éditions scientifiques, 1892).

31 Capitaine Commandant Lefebure, L'Éducation physique en Suède (Brussels: H. Lamertin, 1903).

32 Lefebure (1903), xi. 
held at the Institute of Education, University of London, or a conference on Pulverdampf und Kreidestaub [Gun Smoke and Chalk Dust] organised in Switzerland in 2015.33

Yet, there is a danger of overestimating formal similarities and underestimating cultural path dependencies. The popular but at least naïve reading of what is called the world polity thesis suggests that schools all over the world are in fact more or less the same. Accordingly, it is suggested that due to specific "world forces," that is, some "cultural principles exogenous to any specific nation-state and its historical legacy," ${ }^{34}$ the developments of schooling and curricula in the different nation states "show surprising degrees of homogeneity around the world" 35 and that "variance across national societies is less noticeable than most arguments would have had it," so that we may speak of a "world curriculum" in the "global village," indicating the "relative unimportance of the national, so far as mass curricular outlines go." ${ }^{66}$ The articles in this issue show that we are well advised to be more careful and understand the different social and cultural ambitions and visions behind the implementation of a particular school subject, for any particular school subject is a part of the overall curriculum designed to fabricate the future citizen of the particular nation-state, and these citizens were quite different. ${ }^{37}$

Evidently, the school and its system of organising educational careers of the students is less sensitively oriented towards the inward morality than today's educational research combatants for a better world may wish, and it is less nationally inherent than its rhetoric suggests. The history of physical education is an excellent example for learning not only about the history of physical education but also about the international and martial agenda that are and were compiled within dominant modes in constructing the nation-states. The history of physical education is therefore an object lesson not only of schooling but also of the vulnerability of educational research to reinforcing discursive topoi rather than to examine them. The fact that it is an international and historical journal such as the Nordic Journal of Educational History that offers a special issue for this attempt is not a coincidence, for it is devotedlike other historical journals in education with clearly international editorial boards, such as Paedagogica Historica or the Bildungsgeschichte: International Journal for the Historiography of Education - to deconstructing myths, reconstructing its development and to contribute to a better understanding of schooling.

The guest editors wish to express their gratefulness to the Editorial Team of the Nordic Journal of Educational History for accepting the idea of this special issue,

33 See Gary McCulloch and Georgina Brewis (Guest Editors), "Education, War and Peace," Paedagogica Historica 52, no. 1-2 (2016); Lukas Boser et al., eds. Pulverdampf und Kreidestaub: Beiträge zum Verhältnis zwischen Militär und Schule in der Schweiz im 19. und 20. Jahrhundert (Bern: Bibliothek am Guisanplatz, 2016).

34 John W Meyer and Francisco O. Ramirez, "The World Institutionalization of Education," in Discourse Formation in Comparative Education, ed. Jürgen Schriewer (Frankfurt: Peter Lang Publishing, 2000), 115.

35 John W. Meyer, "Introduction," in School Knowledge for the Masses: World Models and National Primary Curricular Categories in the Twentieth Century, ed. John W. Meyer, David H. Kamens, and Aaaron Benavot (Washington D.C.: Falmer Press, 1992), 2-5.

36 Meyer (1992), 6-9.

37 Daniel Tröhler, Thomas S. Popkewitz, and David F. Labaree, eds., Schooling and the Making of Citizens in the Long Nineteenth Century: Comparative Visions (New York: Routledge, 2011). 
which can hopefully keep its promise that the history of physical education is, as it is the case with any other school subject, much more than the history of physical education. It is, in fact, a contribution to the somewhat hidden fact that there was indeed a pre-national(ist) Europe constituted by an educated public communicating in different networks like academies, expressing itself in different forms of publications and foremost in correspondences. They were the bearers of connecting visions of the future with education, paving the way for the emerging nation-states to incorporate and institutionalise this educationalised culture by transforming educational practices to binding curricula in the service of the fabrication of future loyal citizens. 


\section{References}

Angerstein, Wilhelm. Zur Wehrgymnastik und militärischen Jugenderziehung. Nach zwei Vorträgen, gehalten im Berliner Turnlehrer-Verein. Berlin: W. E. Angerstein, 1880.

Arnold, Thomas. Sermons Preached in the Chapel of Rugby School. London: B. Fellowes, 1833.

Berg, Anne. Kampen om befolkningen: Den svenska nationsformeringens utveckling och sociopolitiska förutsättningar ca 1780-1860. Uppsala: Uppsala universitet, 2011.

Boser, Lukas, Patrick Bühler, Michèle Hofmann, and Philippe Müller, eds. Pulverdampf und Kreidestaub: Beiträge zum Verhältnis zwischen Militär und Schule in der Schweiz im 19. und 20. Jahrhundert. Bern: Bibliothek am Guisanplatz, 2016.

Carlquist, Gunnar, ed. Svensk uppslagsbok, vol 17. Malmö: Svensk Uppslagsbok AB, 1937.

Delheye, Pascal. "Struggling for Gymnastics in Belgium: The Rhetorics of the Battle of the Systems (1860-1914)." Stadion: Internationale Zeitschrift für Geschichte des Sports 32, no. 1 (2006).

Demenÿ, Georges. L'Éducation physique en Suède. Paris: Société d'éditions scientifiques, 1892.

Eichel, Wolfgang, Norbert Heise, Eberhard Jeran, Willi Schröder, and Helmut Westphal. Geschichte der Körperkultur in Deutschland 1789-1917, Band 2. Berlin: Sportverlag, 1973.

GutsMuths, Johann Christoph Friedrich, Gymnastik für die Jugend: Enthalten eine praktische Anweisung zu Leibesübungen. Schnepfenthal: Verlage der Buchhandlung der Erziehungsanstalt, 1793.

GutsMuths, Johann Christoph Friedrich, Kort Anviisning til Legemsøvelser: Et Udtog af Gutsmuths Gymnastik, trans. V. K. Hjort. Copenhagen: S. Poulsen, 1799.

GutsMuths, Johann Christoph Friedrich, Gymnastics for Youth: Or a Practical Guide to Healthful and Amusing Exercises for the Use of Schools ... Freely translated from the German of C.G. Salzmann. London: F. Johnson, St. Paul's Church-Yard, 1800.

Horlacher, Rebekka, and Daniel Tröhler, eds. Sämtliche Briefe an Johann Heinrich Pestalozzi, Band 1. Zurich: NZZ Libro, 2009.

Juvenal. The Sixteen Satires, 3rd ed., trans. Peter Green. London: Penguin Books, 2004.

Korsgard, Ove. “Gymnastik i kosmisk perspektiv.” In Den gamle nyreligiøsitet: Vestens glemte kulturarv, edited by Mette Buchardt and Pia Rose Böwadt, 251-66. Copenhagen: Forlaget Anis, 2003.

Korsgard, Ove. "Gymnastik og romantik: med Pehr Henrik Ling som optik." In Romantikkens verden: Natur, menneske, samfund, kunst og kultur, edited by Ole Høiris and Thomas Ledet, 231-47. Aarhus: Aarhus Universitetsforlag, 2008.

Larsson, Esbjörn. Från adlig uppfostran till borgerlig utbildning: Kungl. krigsakademien mellan åren 1792 och 1866. Uppsala: Uppsala universitet, 2005.

Leonard, Fred Eugene. Physical Education in Denmark. n. p., 1918.

Lefebure, Capitaine Commandant. L'Éducation physique en Suède. Brussels: H. Lamertin, 1903.

Ljunggren, Jens, Kroppens bildning: Linggymnastikens manlighetsprojekt 1790-1914. Stockholm: Symposion, 1999. 
Maier, Alexander. "Bildung zur Nation. Geschichtserzählung und kulturelle Identität als sakral-pädagogisches Programm bei Nikolai Grundtvig." Bildungsgeschichte: International Journal for the Historiography of Education 5, no. 2 (2015), 162-81.

Mayeur, Françoise. Histoire de l'enseigenment et de léducation III: 1789-1930. Paris: Perrin, 1981.

Meyer, John W. "Introduction." In School Knowledge for the Masses: World Models and National Primary Curricular Categories in the Twentieth Century, edited by John W. Meyer, David H. Kamens, and Aaaron Benavot, 1-16. Washington D.C.: Falmer Press, 1992.

Meyer, John W., and Francisco O. Ramirez. "The World Institutionalization of Education." In Discourse Formation in Comparative Education, edited by Jürgen Schriewer, 111-32. Frankfurt: Peter Lang Publishing, 2000.

McCulloch, Gary, and Georgina Brewis (Guest Editors). "Education, War and Peace." Paedagogica Historica 52, nos. 1-2 (2016).

Neumann, Albert Constatin. Die Heil-Gymnastik: oder die Kunst der Leibesübungen, angewandt zur Heilung von Krankheiten nach dem Systeme des Schweden Ling und seiner Schüler Branting, Georgii und de Ron, sowie nach eigenen Ansichten und Erfahrungen; ein Bericht nach einer auf Kosten des Preussischen Staats unternommenen Reise nach Stockholm, London und St. Petersburg. Berlin: Jeanrenaud, 1852.

Pestalozzi, Johann Heinrich. "Über Körperbildung als Einleitung einer Elementargymnastik, in einer Reihenfolge körperlicher Übungen.” In J. H. Pestalozzi, Sämtliche Werke, Kritische Ausgabe, Band 20, 45-68. Zürich: Orell Füssli, 1956.

Rothstein, Hugo. Die Gymnastik, nach dem Systeme des Schwedischen Gymnasiarchen P. H. Ling. Zweiter Abschnitt: Die Pädagogische Gymnastik. Berlin: Schröder, 1847.

Rothstein, Hugo. Die Gymnastik, nach dem Systeme des Schwedischen Gymnasiarchen P. H. Ling. Dritter Abschnitt: Die Heilgymnastik. Berlin: Schröder, 1847.

Rothstein, Hugo. Die Gymnastik, nach dem Systeme des Schwedischen Gymnasiarchen P. H. Ling. Vierter Abschnitt: Die Wehrgymnastik. Berlin: Schröder, 1851.

Tröhler, Daniel. "The German Geisteswissenschaftliche Pädagogik and the ideology of Bildung." In Languages of Education: Protestant Legacies, National Identities, and Global Aspirations, edited by Daniel Tröhler, 148-163. New York: Routledge, 2011.

Tröhler, Daniel. "Educationalization of Social Problems and the Educationalization of the Modern World." In Encyclopedia of Educational Philosophy and Theory, edited by Michael A. Peters. Singapore: Springer, 2016.

Tröhler, Daniel. "Curriculum History or the Educational Construction of Europe in the Long Nineteenth Century." European Educational Research Journal 15, no. 3 (2016), 279-97.

Tröhler, Daniel. "Curriculum History in Europe: A Historiographic Added Value." Nordic Journal of Educational History 3, no. 1 (2016), 3-24.

Tröhler, Daniel, Thomas S. Popkewitz, and David F. Labaree, eds. Schooling and the Making of Citizens in the Long Nineteenth Century: Comparative Visions. New York: Routledge, 2011.

Ulrich, Johann August Heinrich. "Geschichte des Philanthropins zu Dessau." In Pragmatische Geschichte der vornehmsten katholischen und protestantischen 
Gymnasien und Schulen in Deutschland aus authentischen Originalnachrichten, Erster Band, 2-292. Leipzig: Weygandsche Buchhandlung, 1780.

Villaume, Peter. "Von der Bildung des Körpers in Rücksicht auf die Vollkommenheit und Glückseligkeit des Menschen, oder über die physische Erziehung insonderheit." In Allgemeine Revision des gesammten Schul- und Erziehungswesens von einer Gesellschaft praktischer Erzieher, Vol. VIII, 211-492. Vienna: Rudolf Gräffer und Compani, Schulbuchhandlung, 1787. 